\title{
EFEKTIVITAS IMPLEMENTASI MODUL BELAJAR AKUNTANSI PADA KELAS XI KOMPETENSI KEAHLIAN AKUNTANSI SMK N 1 YOGYAKARTA
}

\author{
Oleh : \\ Ninda Okta Winggani ${ }^{1}$ \\ Sukanti ${ }^{2}$
}

\begin{abstract}
Abstrak
Penelitian ini bertujuan untuk mengetahui efektivitas implementasi sistem modul belajar Akuntansi pada kelas XI kompetensi keahlian Akuntansi SMK N 1 Yogyakarta tahun ajaran 2012/2013 ditinjau dari indikator kemudahan dalam penyampaian materi, adanya solusi atas keterbatasan dalam pembelajaran, variasi dalam pembelajaran, penilaian diri dan pembelajaran tuntas. Penelitian ini merupakan penelitian deskriptif yang dilakukan di SMK N 1 Yogyakarta. Subjeknya adalah siswa kelas XI Kompetensi Keahlian Akuntansi SMK N 1 Yogyakarta yang berjumlah 65 siswa dan 3 orang guru mata diklat Akuntansi. Metode pengumpulan data dengan menggunakan angket penelitian.Teknik analisis data dengan menggunakan tabel, tabel distribusi frekuensi, grafik dan pengukuran gejala pusat. Hasil penelitian ditinjau dari perspektif guru menunjukkan efektivitas implementasi sistem modul belajar Akuntansi secara keseluruhan termasuk dalam kategori efektivitas tinggi dengan rerata hitungnya sebesar 110,67 dan untuk hasil efektivitas per indikator menunjukkan kelima indikator juga termasuk dalam kategori efektivitas tinggi. Hasil penelitian ditinjau dari perspektif siswa menunjukkan efektivitas implementasi sistem modul belajar Akuntansi secara keseluruhan termasuk dalam kategori efektivitas tinggi dengan rerata hitungnya yaitu sebesar 116,63 dan untuk hasil efektivitas per indikator menunjukkan kelima indikator juga termasuk dalam kategori efektivitas tinggi. Kata kunci: Efektivitas, Implementasi Sistem Modul Belajar Akuntansi
\end{abstract}

\section{Abstract}

This study aims to determine the effectiveness of implementation Accounting learning modules system in class XI Accounting skills competency SMK N 1 Yogyakarta academic year of 2012/2013 judged from the indicators of the ease of presentation, the solution to the limitations of the study, variations in learning, selfassessment and mastery learning.This research is a descriptive study conducted at SMK N 1 Yogyakarta. The subjects are the student from class XI Accounting Skills Competency SMK N 1 Yogyakarta,there are 65 students and 3Accounting teachers. Data is collected by using a questionnaire. Data analysis technique using tables, frequency distribution tables, graphs and measurements of central symptoms. The results judged from the perspective of teachers show the

\footnotetext{
${ }^{1}$ Alumni Prodi Pendidikan Akuntansi Fakultas Ekonomi Universitas Negeri Yogyakarta ${ }^{2}$ Staf Pengajar Jurusan P. Akuntansi Fakultas Ekononi Universitas Negeri Yogyakarta
} 
effectiveness of implementation accounting learning modules systems as a whole is included in the category of high effectiveness with the mean score of 110.67 and for the results of the effectiveness of each indicator show the fifth indicators are also included in the category of high effectiveness. The results judged from the perspective of the student show the effectiveness of implementation Accounting learning modules systems as a whole included in the category of high effectiveness with the mean score of 116.63 and for the results of the effectiveness of each indicator show the fifth indicators are also included in the category of high effectiveness.

Keywords: Effectiveness, Learning Modules Accounting System Implementation

\section{A. Pendahuluan}

Sesuai dengan kurikulum 2006 KTSP menuntut siswa untuk belajar lebih mandiri.Akhir-akhir ini makin banyak perhatian pada pengajaran individual dan kepercayaan akan kemampuan individu untuk belajar sendiri. Pengajaran lebih ditujukan kepada proses belajar yakni membimbing siswa untuk menguasai teknik belajar untuk mencari sendiri apa yang diperlukannya. Pengajaran individual ini dapat dipandang sebagai reaksi terhadap pengajaran klasikal dengan kelas yang terlampau besar dan padat sehingga guru atau tenaga pengajar tidak dapat memberikan bantuan individual, bahkan sering tidak dapat mengenal siswa satu demi satu. Selain itu, setiap siswa juga memiliki perbedaan cara belajar masing-masing.

Pengajaran klasikal yang menggunakan proses belajar mengajar yang sama bagi setiap siswa tidak akan sesuai dengan kebutuhan dan kepribadian setiap siswa (S. Nasution, 2011: 204). Oleh karena itu diperlukan perangkatperangkat untuk membantu siswa untuk belajar lebih mandiri.Perangkat tersebut salah satunya bahan ajar yang berbentuk modul.Penyusunan modul ini dimaksudkan untuk mempermudah siswa dalam memahami materi secara individu. Selain itu, modul juga diharapkan akan dapat memberi kontribusi yang besar pada hasil dari proses pembelajaran yang dilakukan. Dengan adanya modul siswa memiliki alternatif sumber belajar dalam proses pembelajaran selain buku teks dan guru.

Modul dapat dirumuskan sebagai suatu unit yang lengkap yang berdiri sendiri dan terdiri atas suatu rangkaian kegiatan belajar yang disusun untuk membantu siswa mencapai sejumlah tujuan yang dirumuskan secara khusus dan jelas. Sistem pengajaran dengan modul ini bertujuan terutama untuk meningkatkan efisiensi dan efektivitas kegiatan belajar mengajar di sekolah, terutama yang berkaitan dengan peningkatan kemandirian siswa dalam proses pembelajaran dan tercapainya tujuan penggunaan modul secara optimal. Namun demikian, berdasarkan observasi awal yang saya lakukan di SMK N 1 Yogyakarta menunjukkan sebagian besar pengajaran modul di sekolah masih belum optimal, hal ini dibuktikan dengan masih tingginya keterlibatan guru dalam pembelajaran modul sehingga prinsip belajar mandiri yang menjadi tujuan awal penyusunan modul belajar tidak tercapai.

Berdasarkan hasil pengamatan di SMK Negeri 1 Yogyakarta, pembelajaran menggunakan modul sudah cukup lama diterapkan. Namun 
demikian, praktik penggunaan modul di sekolah secara khususnya adalah modul Akuntansi masih banyak menimbulkan perdebatan. Perdebatan ini mengenai apakah penggunaan modul sebagai bahan ajar sudah efektif dan dapat mendatangkan manfaat bagi pihak-pihak yang terkait seperti guru dan siswa. Dalam kaitannya dengan efektivitas penggunaan modul belajar Akuntansi ada beberapa pihak yang berpendapat bahwa penggunaan modul dalam proses belajar Akuntansi tidaklah penting, tetapi di sisi lain ada pihak yang menganggap bahwa penggunaan modul belajar lebih efektif dibandingkan dengan buku teks dalam pembelajaran Akuntansi, sehingga tidak jarang pihak sekolah mewajibkan tiap guru untuk menyusun suatu modul untuk mata diklat yang diampunya, dalam hal ini adalah Akuntansi.

Di sisi lain, masih tidak sedikit pula pihak sekolah yang kurang memperhatikan penggunaan modul belajar karena dianggap kurang maksimalnya pencapaian tujuan-tujuan penggunaan modul dalam kegiatan pembelajaran yang berakibat pada kurang digunakannya modul belajar pada sekolah-sekolah secara umum sebagai bahan ajar dan sumber belajar dalam kegiatan umum pembelajaran. Dalam hal ini, guru akan menggunakan buku teks dalam menyampaikan materi pada siswa. Dalam hal ini buku teks merupakan satu-satunya sumber belajar sehingga siswa akan cenderung berpusat pada penjelasan guru dan bersifat pasif dalam mengikuti kegiatan belajar mengajar. Hal ini dapat berakibat pada kegiatan belajar mengajar yang menjadi kurang efektif dan efisien serta siswa mendapat pengetahuan yang terbatas dari satu sumber saja yaitu buku teks tanpa mengacu pada referensi lain. Efektivitas implementasi sistem modul belajar Akuntansi di SMK Negeri 1 Yogyakarta juga belum seluruhnya diketahui oleh pihak-pihak terkait (guru dan siswa).

Berbagai hal mengenai pro dan kontra efektivitas modul ini, mendorong peneliti untuk melakukan penelitian yang lebih khusus mengenai efektivitas penerapan sistem modul belajar Akuntansi di SMK Negeri 1 Yogyakarta untuk memperjelas kenyataan yang ada sebenarnya di lapangan. Dengan mengetahui fakta yang sebenarnya terjadi di sekolah dalam hal ini SMK Negeri 1 Yogyakarta maka diharapkan pihak-pihak yang terkait dapat mengambil sikap yang paling tepat untuk menyikapi dan menanggapinya. Oleh karena itu, pada kesempatan kali ini peneliti akan meneliti tentang "Efektivitas Implementasi Sistem Modul Belajar Akuntansi pada Kelas XI Kompetensi Keahlian Akuntansi SMK Negeri 1 Yogyakarta Tahun Ajaran 2012/2013”.

\section{Tinjauan tentang Belajar}

Belajar merupakan suatu proses perubahan tingkah laku berkat pelatihan dan pengalaman. Belajar dalam hal ini harus dilakukan dengan sengaja, direncanakan sebelumnya dengan struktur tertentu (Oemar Hamalik, 2010: 154). Proses itu sendiri berlangsung melalui serangkaian pengalaman sehingga terjadi modifikasi tingkah laku seseorang atau terjadi penguatan pada tingkah laku yang dimiliki sebelumnya. Belajar merupakan suatu proses perubahan tingkah laku sebagai hasil dari interaksi individu dengan lingkungannya dalam memenuhi kebutuhannya (Sugihartono,dkk, 2007: 74). 


\section{Tinjauan tentang Sistem Modul belajar}

Modul dapat dirumuskan sebagai suatu unit yang lengkap yang berdiri sendiri dan terdiri atas sesuatu rangkaian kegiatan belajar yang disusun untuk membantu siswa mencapai sejumlah tujuan yang dirumuskan secara khusus dan jelas ( S.Nasution, 2011: 205). Sedangkan menurut E. Mulyasa (2006: 231) modul merupakan paket belajar mandiri yang meliputi serangkaian pengalaman belajar yang direncanakan secara sistematis untuk membantu siswa mencapai tujuan belajar yang telah ditetapkan sebelumnya.

Fungsi modul adalah sebagai alat untuk mengkomunikasikan unit pelajaran kepada siswa secara individual untuk kemudian dipahami, dimengerti dan dapat menyelesaikan tugas-tugas yang ada, dengan sedikit mungkin layanan dan bimbingan dari guru sehingga minimal menguasai $75 \%$ dari unit tersebut ("konsep mastery learning"), yang dicek melalui evaluasi dengan tes pada tiap akhir modul. Guru bertindak sebagai fasilitator, mediator dan pembimbing siswa, apabila mengalami kesulitan dalam memahami materi.

3. Tinjauan tentang Efektivitas Implementasi Sistem Modul Belajar Akuntansi

Modul belajar Akuntansi merupakan modul pelajaran yang digunakan sebagai sumber belajar atau bahan ajar mata diklat Akuntansi yang berisi materi pelajaran Akuntansi, metode pelajaran serta evaluasi pada tiap akhir pokok bahasan. Dimana modul belajar Akuntansi ini diharapkan akan dapat membantu guru dan siswa untuk mencapai tujuan pembelajaran Akuntansi yaitu agar siswa mampu untuk mencapai hasil belajar Akuntansi yang maksimal sesuai dengan kemampuan dan pengalaman masing-masing siswa.

Modul Akuntansi biasanya disusun secara sistematis sesuai dengan penyajian materi Akuntansi yang diajarkan di SMK. Karena Akuntansi merupakan mata diklat dengan menggunakan siklus artinya materi yang disajikan atau yang diajarkan akan senantiasa berurutan dari materi pelajaran dasar sampai yang kompleks maka modul Akuntansi juga biasanya sudah dibuat sedemikian rupa sesuai dengan urutan materi. Selain itu, dalam setiap pokok bahasan juga terdapat instrumen penilaian yang memungkinkan siswa untuk dapat mengevaluasi sendiri hasil belajarnya dan menilai kemajuan belajar yang telah dilakukan tanpa harus tergantung pada guru mata diklat yang bersangkutan.

Efektivitas implementasi sistem modul belajar dinyatakan sebagai tingkat pencapaian tujuan awal dirancangnya suatu modul untuk melengkapi dan mendukung proses belajar mengajar. Dalam hal ini, efektivitas implementasi sistem modul belajar Akuntansi didasarkan pada tingkat pencapaian tujuan penyusunan dan pengimplementasian modul belajar menurut PMPTK Departemen Pendidikan Nasional dan menurut S. Nasution (2011: 205-206).

4. Tinjauan tentang Perspektif Guru dan Prspektif Siswa

Dalam penelitian ini, perspektif diartikan sebagai sudut pandang manusia dalam memilih opini, kepercayaan, dan lain-lain.Secara lebih 
khusus dalam hal ini perspektif dapat diartikan sebagai sudut pandang guru dalam memilih opini dan kepercayaan atas penggunaan atau implementasi sistem modul belajar Akuntansi pada kelas XI kompetensi keahlian Akuntansi SMK Negeri 1 Yogyakarta tahun ajaran 2012/2013.

Dalam penelitian ini, perspektif diartikan sebagai sudut pandang manusia dalam memilih opini, kepercayaan, dan lain-lain. Secara lebih khusus dapat diartikan sebagai sudut pandang siswa kelas XI kompetensi keahlian Akuntansi dalam memilih opini dan kepercayaan atas penggunaan atau implementasi sistem modul belajar Akuntansi pada kelas XI kompetensi keahlian Akuntansi SMK Negeri 1 Yogyakarta tahun ajaran 2012/2013.

\section{Kerangka Berpikir}

Penelitian ini akan membahas tentang Efektivitas Implementasi Sistem Modul Belajar Akuntansi pada Kelas XI Kompetensi Keahlian Akuntansi SMK Negeri 1 Yogyakarta Tahun Ajaran 2012/2013. Berdasarkan hubungan pertautan yang mungkin terjadi antara teori maka dapat dinyatakan suatu kerangka berpikir yaitu jika tujuan digunakannya atau diterapkannya sistem modul sebagai alternatif bahan ajar dan sumber belajar sudah dapat tercapai yang ditunjukkan dengan adanya kemudahan dalam penyampaian materi dengan menggunakan implementasi sistem modul belajar Akuntansi, terdapat solusi atas keterbatasan-keterbatasan dalam proses pembelajaran (waktu, ruang dan daya indera, baik guru maupun siswa), terdapat variasi dalam pembelajaran dengan menggunakan modul belajar Akuntansi, siswa dapat melakukan penilaian diri (self assessment), dan siswa dapat menguasai materi pelajaran secara tuntas (mastery learning) maka implementasi sistem modul belajar Akuntansi dapat dikatakan efektif ( efektivitas tinggi).

\section{B. Metode Penelitian}

\section{Tempat dan Waktu Penelitian}

Penelitian ini dilaksanakan di SMK N 1 Yogyakarta yang beralamat di Jalan Kemetiran Kidul 35 Yogyakarta. Waktu pelaksanaan penelitian ini adalah selama tiga hari yaitu pada tanggal 20-22 Desember 2012.

\section{Jenis Penelitian}

Jenis penelitian ini adalah penelitian deskriptif. Penelitian deskriptif adalah penelitian yang bertujuan menggambarkan secara sistematik dan akurat fakta dan karakteristik mengenai populasi atau mengenai daerah tertentu. Penelitian ini berusaha menggambarkan situasi atau kejadian. (Saiffuddin Azwar, MA). Dalam penelitian deskriptif cenderung tidak perlu mencari atau menerangkan saling hubungan dan menguji hipotesis. Penelitian ini diarahkan untuk menetapkan sifat suatu situasi pada waktu penyelidikan dilakukan. Dalam penelitian deskriptif tidak ada perlakuan yang diberikan seperti yang ditemui dalam penelitian eksperimental. 


\section{Subjek Penelitian}

Subjek penelitian ini adalah:

a. Siswa kelas XI kompetensi keahlian Akuntansi yang berasal dari dua kelas ( XIAK1 dan XIAK2) dengan jumlah 68 siswa. Namun, pada saat pengumpulan data dilaksanakan terdapat 3 siswa yang tidak hadir dikarenakan sakit, sehingga subjek penelitian menjadi 65 siswa.

b. Guru kelas XI kompetensi keahlian Akuntansi yang terdiri dari 3 orang guru. Dimana masing-masing guru tersebut mengampu mata diklat Akuntansi Biaya, Akuntansi Keuangan dan Dasar Kompetensi Keahlian.

\section{Definisi Operasional}

Definisi operasional yang dipakai sebagai berikut:

a. Modul Belajar Akuntansi

Modul belajar Akuntansi adalah sarana pembelajaran Akuntansi secara tertulis yang disusun secara sistematis agar siswa dapat mempelajari dan memahami materi pembelajaran Akuntansi serta dapat mencapai kompetensi yang telah ditentukan sebelumnya secara optimal.Dalam penelitian ini yang dimaksud modul belajar Akuntansi adalah modul belajar untuk mata diklat Akuntansi kelas XI kompetensi keahlian Akuntansi di SMK N 1 Yogyakarta tahun ajaran 2012/2013.

b. Efektivitas Implementasi Sistem Modul Belajar Akuntansi

Efektivitas sering dikaitkan dengan masalah keberhasilan yaitu suatu keadaan yang mencerminkan tingkat pencapaian tujuan yang diharapkan (Al-bantany, 2009).Efektivitas dalam implementasi modul dinyatakan sebagai tingkat pencapaian awal dirancangnya modul untuk melengkapi, mendukung dan mempermudah penyampaian materi dalam kegiatan belajar mengajar disekolah melalui alternatif sumber belajar yang bervariatif. Secara khusus tujuan dari dirancang dan disusunnya modul belajar Akuntansi adalah sebagai alternatif bahan ajar dan sumber belajar dalam proses berlangsungnya kegiatan belajar mengajar Akuntansi. Efektivitas penggunaan sistem implementasi bahan ajar modul dalam hal ini ditekankan dari perspektif guru dan perspektif siswa yang secara langsung terlibat dalam proses kegiatan belajar mengajar di sekolah. Apabila guru dan siswa dapat merasakan manfaat secara langsung dari implementasi sistem modul yang digunakan ini berarti bahwa apa yang telah menjadi tujuan awal dari digunakannya sistem modul dapat dikatakan sudah tercapai dan terpenuhi.

Penelitian ini membahas tentang Efektivitas Implementasi Sistem Modul Belajar Akuntansi pada Kelas XI Kompetensi 
Keahlian Akuntansi SMK Negeri 1 Yogyakarta Tahun Ajaran 2012/2013. Berdasarkan hubungan pertautan yang mungkin terjadi maka dapat dinyatakan jika tujuan digunakannya atau diterapkannya sistem modul sebagai alternatif bahan ajar dan sumber belajar sudah dapat tercapai yang ditunjukkan dengan adanya kemudahan dalam penyampaian materi dengan menggunakan implementasi sistem modul belajar Akuntansi, terdapat solusi atas keterbatasan-keterbatasan dalam proses pembelajaran (waktu,ruang dan daya indera, baik guru maupun siswa), terdapat variasi dalam pembelajaran dengan menggunakan modul belajar Akuntansi, siswa dapat mengikuti program pengajaran sesuai dengan kecepatan dan kemampuan masingmasing siswa sendiri(self assessment), lebih banyak siswa yang dapat belajar mandiri, dapat mengetahui hasil belajar sendiri, dapat membangkitkanmotivasi siswa untuk belajar dengan baik sertatercapainya prinsip penguasaan bahan pelajaran secara optimal menurut PMPTK Departemen Pendidikan Nasional (2008) dan Nasution (2011: 205-206 ), maka Implementasi sistem modul belajar Akuntansi dapat dikatakan telah efektif (efektivitas tinggi).

\section{Prosedur Penelitian} berikut:

Langkah-langkah pada penelitian yang dilaksanakan adalah sebagai

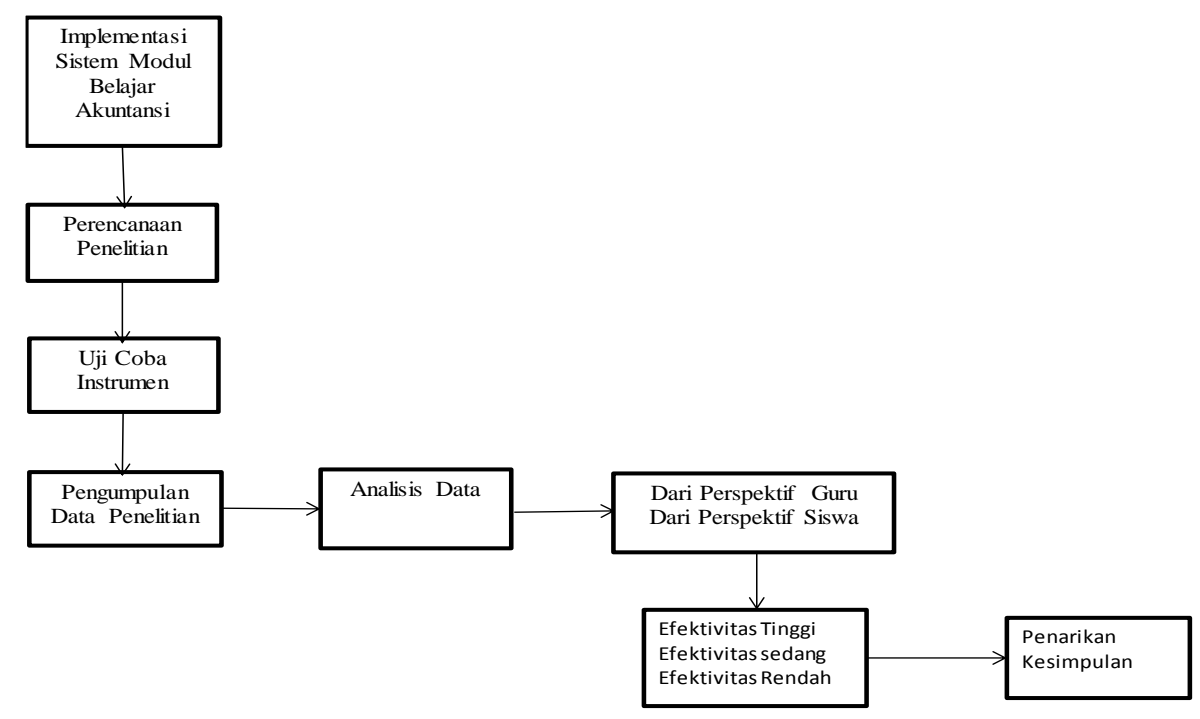

\section{Metode Pengumpulan Data}

Angket

Angket merupakan sejumlah pernyataan tertulis yang digunakan untuk memperoleh informasi dari responden dalam arti laporan pribadinya atau hal-hal yang responden ketahui.Jenis angket atau kuesioner dalam penelitian ini adalah kuesioner tertutup dengan skala Likert modifikasi empat (4) jawaban. 


\section{Instrumen Penelitian}

a. Penyusunan Instrumen

Dengan skala Likert, maka variabel yang akan diukur dijabarkan menjadi subvariabel. Kemudian subvariabel dijabarkan menjadi komponen-komponen yang dapat terukur. Komponenkomponen yang terukur ini kemudian dijadikan sebagai titik ukur untuk menyusun item instrumen yang dapat berupa pernyataan yang kemudian dijawab oleh responden. Berikut dijelaskan mengenai penyusunan kisi-kisi instrumen Efektivitas Implementasi Sistem Modul Belajar Akuntansi untuk subjek penelitian dari pihak guru dan siswa.

\begin{tabular}{|c|c|c|c|c|}
\hline No & Indikator & Subindikator & No.Butir & $\sum$ Butir \\
\hline 1. & $\begin{array}{l}\text { Adanya kemudahan } \\
\text { dalam penyampaian } \\
\text { materi dengan } \\
\text { menggunakan modul } \\
\text { belajar Akuntansi }\end{array}$ & $\begin{array}{l}\text { a. Penyajian materi } \\
\text { b. Struktur kebahasaan }\end{array}$ & $\begin{array}{l}1,2 \\
3,4\end{array}$ & $\begin{array}{l}2 \\
2\end{array}$ \\
\hline 2. & $\begin{array}{l}\text { Terdapat solusi atas } \\
\text { keterbatasan- } \\
\text { keterbatasan dalam } \\
\text { proses pembelajaran } \\
\text { (waktu, ruang, dan daya } \\
\text { indera baik siswa } \\
\text { maupun guru) }\end{array}$ & $\begin{array}{l}\text { a. Kemandirian belajar } \\
\text { b. Fleksibilitas }\end{array}$ & $\begin{array}{l}5,6 \\
7,8,9\end{array}$ & $\begin{array}{l}2 \\
3\end{array}$ \\
\hline 3. & $\begin{array}{l}\text { Terdapat variasi dalam } \\
\text { pembelajaran } \\
\text { menggunakan modul } \\
\text { belajar Akuntansi }\end{array}$ & $\begin{array}{ll}\text { a. Motivasi dan gairah } \\
\text { belajar } \\
\text { b. Metode pembelajaran } \\
\text { c. Interaksi dengan lingkungan } \\
\text { dan sumber belajar } \\
\text { d. KerjasamaTanggungjawab } \\
\text { e. Variasi kegiatan belajar } \\
\text { f. Peran guru } \\
\text { g. Peran siswa } \\
\text { h. Tujuan } \\
\text { i. Bantuan individual } \\
\text { j. Kebebasan dari rutinitas } \\
\text { k. Meningkatkan } \\
\text { keguruan }\end{array}$ & $\begin{array}{l}10,11 \\
12,13 \\
14,15 \\
16,17 \\
18,19 \\
20 \\
21,22 \\
23,24 \\
25,26 \\
27 \\
28,29 \\
30\end{array}$ & $\begin{array}{l}2 \\
2 \\
2 \\
2 \\
2 \\
1 \\
2 \\
2 \\
2 \\
1 \\
2 \\
1\end{array}$ \\
\hline 4. & 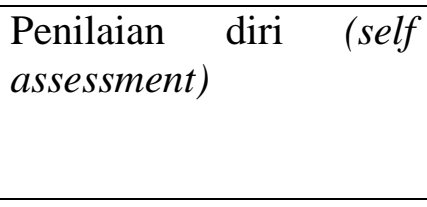 & $\begin{array}{ll}\text { a. } & \text { Balikan/ feedback } \\
\text { b. } & \text { Pengajaran remedial } \\
\text { c. } & \text { Pengayaan } \\
\text { d. } & \text { Evaluasi formatif } \\
\end{array}$ & $\begin{array}{l}31,32 \\
33,34 \\
35 \\
36\end{array}$ & $\begin{array}{l}2 \\
2 \\
1 \\
1 \\
\end{array}$ \\
\hline 5. & $\begin{array}{l}\text { Pembelajaran tuntas } \\
\text { (mastery learning) }\end{array}$ & $\begin{array}{l}\text { a. Penguasaan materi } \\
\text { b. Ketuntasan belajar } \\
\text { c. Keberhasilan belajar }\end{array}$ & $\begin{array}{l}37 \\
38 \\
39,40 \\
\end{array}$ & $\begin{array}{l}1 \\
1 \\
2\end{array}$ \\
\hline \multicolumn{4}{|c|}{ Jumlah } & 40 \\
\hline
\end{tabular}




\section{Uji Validitas dan Reliabilitas}

Sebelum instrumen digunakan untuk meneliti, instrumen telah diujicobakan terlebih dahulu agar diperoleh instrumen yang baik, yaitu instrumen yang dapat mengukur apa yang seharusnya diukur. Pada penelitian ini, uji coba instrumen dilaksanakan pada tanggal 23 November 2012 dengan subjek 34 siswa kelas XI AK2 kompetensi keahlian Akuntansi SMK Negeri 7 Yogyakarta tahun ajaran 2012/2013.

1) Uji Validitas Instrumen

Instrumen yang akan digunakan diuji validitasnya terlebih dahulu. Validitas yang digunakan adalah validitas konstruksi (construct validity)..Kemudian untuk mengetahui validitas ini peneliti menggunakan teknik korelasi product moment rumus yang digunakan adalah rumus Korelasi Product Moment dari Pearson yang dikutip dari Suharsimi Arikunto (2009: 72). Rumus Korelasi Product Moment adalah sebagai berikut:

$$
\mathrm{r}_{\mathrm{xy}}=\frac{N \sum X Y-\left(\sum X\right)\left(\sum Y\right)}{\sqrt{\left.\left\{N \sum X^{2}-\left(\sum X\right)^{2}\right\} N \sum Y^{2}-\left(\sum Y\right)^{2}\right\}}}
$$

Keterangan:

$\mathrm{r}_{\mathrm{xy}} \quad$ : Koefisien korelasi antara variabel $\mathrm{X}$ dan $\mathrm{Y}$

$\mathrm{N} \quad$ : Jumlah responden

$\Sigma X \quad$ : Jumlah variabel $X$ sebagai skor faktor

$\Sigma \mathrm{Y}$ : Jumlah variabel Y sebagai total skor faktor

$\Sigma X Y$ : Jumlah perkalian $\mathrm{X}$ dan $\mathrm{Y}$

$\left(\Sigma X^{2}\right)$ : Jumlah kuadrat skor variabel $X$

$\left(\Sigma \mathrm{Y}^{2}\right)$ : Jumlah kuadrat skor variabel $\mathrm{Y}$

Sumber: (Suharsimi Arikunto, 2009: 72)

2) Uji Reliabilitas Instrumen

Reliabilitas berhubungan dengan masalah kepercayaan.Pengujian reliabilitas dilakukan dengan internal consistency, dilakukan dengan mencobakan instrumen sekali saja kemudian data yang diperoleh dianalisis dengan teknik tertentu.Selanjutnya, pengujian reliabilitas dilakukan dengan teknik Alfa Cronbach mengingat jenis data adalah interval atau essay.Rumus yang digunakan adalah rumus Alfa sebagai berikut:

$$
\mathrm{r}_{11}=\left(\frac{n}{n-1}\right)\left(1-\frac{\sum \sigma_{i}^{2}}{\sigma_{i}^{2}}\right)
$$

Dimana :

$\mathrm{r}_{11} \quad=$ reliabilitas yang dicari 
$\begin{array}{ll}\sum \sigma_{i}^{2} & =\text { jumlah varians skor tiap-tiap item } \\ \sigma_{i}^{2} & =\text { varians total }\end{array}$

Sumber: (Suharsimi Arikunto, 2009: 109)

\section{Teknik Analisis Data}

Langkah-langkah yang dilakukan oleh peneliti setelah semua data yang diperlukan terkumpul meliputi:

a. Penyajian Data

Penyajian data dilakukan dengan menggunakan:

1) Tabel

2) Tabel Distribusi Frekuesi untuk menyajikan data perspektif siswa

3) Grafik

b. Pengukuran Gejala Pusat (Central Tendency)

1) Menghitung Modus

2) Menghitung Mean

3) Menghitung Median

4) Menghitung Standar Deviasi

5) Penarikan Kesimpulan

Skor penilaian implementasi sistem modul belajar Akuntansi yang diperoleh dari angket kemudian dihitung mean ideal dan standar deviasi ideal selanjutnya dikategorikan ke dalam 3 (tiga) kategori berdasarkan aturan distribusi normal menurut Saiffudin Azwar (2011: 109).

Perhitungan mean (M) ideal dan standar deviasi (SD) ideal dapat dihitung dengan menggunakan rumus:

1) $M i=\frac{1}{2}($ skor tertinggi ideal + skor terendah ideal $)$

2) $S D i=\frac{1}{6}($ skor tertinggi ideal - skor terendah ideal $)$

Aturan distribusi normal untuk kepentingan penggolongan menurut Saiffuddin Azwar (2011: 107) tampak pada gambar di bawah ini:

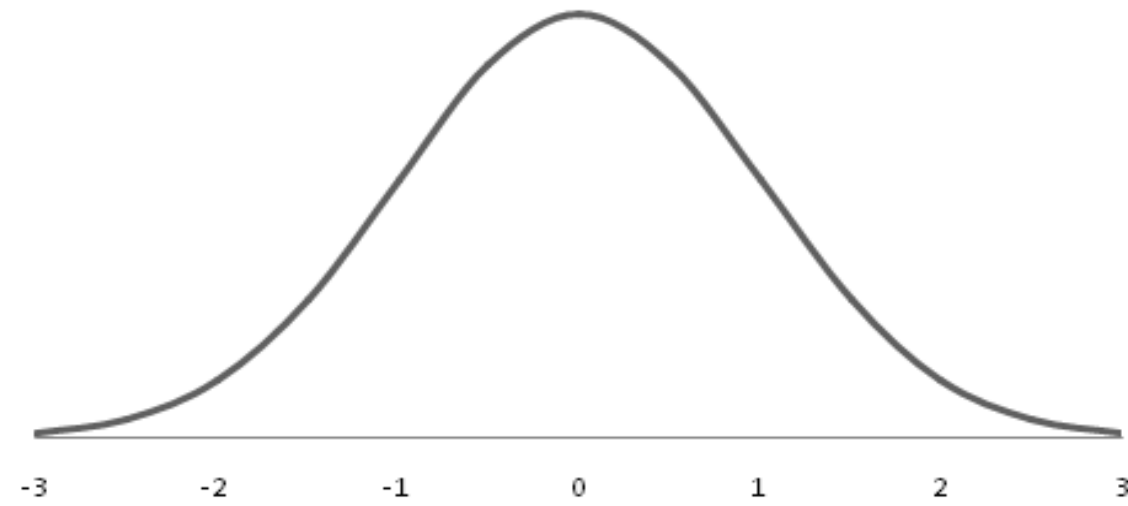


Penggolongan efektivitas implementasi sistem modul belajar Akuntansi ke dalam tiga kategori berimbas keenam satuan standar deviasi dibagi ke dalam 3 bagian sebagai berikut:

Tabel Pedoman Penggolongan Total Nilai (Skor) Efektivitas

\begin{tabular}{|l|l|}
\hline Rentang Nilai ( Skor) & Kategori \\
\hline$\geq(\mathrm{Mi}+1,0 \mathrm{SDi})$ & Tinggi \\
\hline$(\mathrm{Mi}-1,0 \mathrm{SDi})-(\mathrm{Mi}+1,0 \mathrm{SDi})$ & Sedang \\
\hline$<(\mathrm{Mi}-1,0 \mathrm{SDi})$ & Rendah \\
\hline
\end{tabular}

Sumber: (Saiffudin Azwar, 2011: 109)

\section{Hasil Penelitian Dan Pembahasan}

1. Efektivitas Implementasi Sistem Modul Belajar Akuntansi ditinjau dari Perspektif Guru

Apabila melihat pada perhitungan data frekuensi dan melalui program SPSS seri 18,0for windows pada bagian mengenai efektivitas implementasi sistem modul belajar Akuntansi ditinjau dari perspektif guru dapat diketahui bahwa rerata hitungnya adalah sebesar 110,67. Rerata hitung tersebut kemudian dibandingkan dengan skor dalam kriteria kategori yaitu sebesar 105, dimana untuk skor $\geq 105$ termasuk dalam kategori tinggi, sehingga dapat diambil kesimpulan bahwa efektivitas implementasi sistem modul belajar Akuntansi ditinjau dari perspektif guru secara keseluruhan termasuk ke dalam kategori tinggi (efektivitas tinggi).

Efektivitas implementasi sistem modul belajar Akuntansi ditinjau dari perspektif guru dinyatakan dalam 5 indikator yaitu sebagai berikut:

1) Adanya kemudahan dalam penyampaian materi

Apabila melihat pada perhitungan data frekuensi indikator adanya kemudahan dalam penyampaian materi memiliki rerata hitung sebesar 13,33. Rerata hitung tersebut kemudian dibandingkan dengan skor dalam kriteria kategori yaitu sebesar 12 dimana untuk skor $\geq 12$ termasuk dalam kategori tinggi.

2) Terdapat Solusi Atas Keterbatasan dalam Proses Pembelajaran

Apabila melihat pada perhitungan data frekuensi indikator terdapat solusi atas keterbatasan dalam proses pembelajaran ditinjau dari perspektif guru memiliki rerata hitung sebesar 17,00. Rerata hitung tersebut kemudian 
dibandingkan dengan skor dalam kriteria kategori yaitu sebesar 15 , dimana untuk skor $\geq 15$ termasuk dalam kategori tinggi.

3) Terdapat Variasi dalam Pembelajaran

Apabila melihat pada perhitungan data frekuensi indikator terdapat variasi dalam pembelajaran ditinjau dari perspektif guru memiliki rerata hitung sebesar 54,67. Rerata hitung tersebut kemudian dibandingkan dengan skor dalam kriteria kategori yaitu sebesar 54 dimana untuk skor $\geq 54$ termasuk dalam kategori tinggi.

4) Penilaian Diri (Self Assessment)

Apabila melihat pada perhitungan data frekuensi penilaian diri (self assessment) ditinjau dari perspektif guru memiliki rerata hitung sebesar 12,67. Rerata hitung tersebut kemudian dibandingkan dengan skor dalam kriteria kategori yaitu sebesar 12 dimana untuk skor $\geq 12$ termasuk dalam kategori tinggi.

5) Pembelajaran Tuntas (Mastery Learning)

Apabila melihat pada perhitungan data frekuensi indikator pembelajaran tuntas (mastery learning) ditinjau dari perspektif guru memiliki rerata hitung sebesar 13,00. Rerata hitung tersebut kemudian dibandingkan dengan skor dalam kriteria kategori yaitu sebesar 12 , dimana untuk skor $\geq 12$ termasuk dalam kategori tinggi.

b. Efektivitas Implementasi Sistem Modul Belajar Akuntansi Ditinjau dari Perspektif Siswa

Apabila melihat pada perhitungan data frekuensi dan melalui program SPSS seri 18,0for windows pada bagian mengenai efektivitas implementasi sistem modul belajar Akuntansi ditinjau dari perspektif siswa bahwa rerata hitungnya adalah sebesar 116,63. Rerata hitung tersebut kemudian dibandingkan dengan skor dalam kriteria kategori yaitu sebesar 105 dimana untuk skor $\geq 105$ termasuk dalam kategori tinggi, sehingga dapat diambil kesimpulan bahwa efektivitas implementasi sistem modul belajar Akuntansi ditinjau dari perspektif siswa secara keseluruhan termasuk ke dalam kategori tinggi (efektivitas tinggi).

Efektivitas implementasi sistem modul belajar Akuntansi ditinjau dari perspektif siswa dinyatakan dalam 5 indikator yaitu sebagai berikut: 
1) Adanya kemudahan dalam penyampaian materi

Apabila melihat pada perhitungan data frekuensi indikator adanya kemudahan dalam penyampaian materi memiliki rerata hitung sebesar 14,32. Rerata hitung tersebut kemudian dibandingkan dengan skor dalam kriteria kategori yaitu sebesar 12 dimana untuk skor $\geq 12$ termasuk dalam kategori tinggi.

2) Terdapat Solusi Atas Keterbatasan dalam Proses Pembelajaran

Apabila melihat pada perhitungan data indikator terdapat solusi atas keterbatasan dalam proses pembelajaran ditinjau dari perspektif siswa memiliki rerata hitung sebesar 16,62. Rerata hitung tersebut kemudian dibandingkan dengan skor dalam kriteria kategori yaitu sebesar 15 dimana untuk skor $\geq 15$ termasuk dalam kategori tinggi.

3) Terdapat Variasi dalam Pembelajaran

Apabila melihat pada perhitungan data frekuensi indikator terdapat variasi dalam pembelajaran ditinjau dari perspektif siswa memiliki rerata hitung sebesar 57,18. Rerata hitung tersebut kemudian dibandingkan dengan skor dalam kriteria kategori yaitu sebesar 54 dimana untuk skor $\geq 54$ termasuk dalam kategori tinggi.

4) Penilaian Diri (Self Assessment)

Apabila melihat pada perhitungan data frekuensi indikator penilaian diri (self assessment) ditinjau dari perspektif siswa memiliki rerata hitung sebesar 13,52. Rerata hitung tersebut kemudian dibandingkan dengan skor dalam kriteria kategori yaitu sebesar 12 dimana untuk skor $\geq 12$ termasuk dalam kategori tinggi.

5) Pembelajaran Tuntas (Mastery Learning)

Apabila melihat pada perhitungan data frekuensi indikator pembelajaran tuntas (mastery learning) ditinjau dari perspektif siswa memiliki rerata hitung sebesar 14,98. Rerata hitung tersebut kemudian dibandingkan dengan skor dalam kriteria kategori yaitu sebesar 12 dimana untuk skor $\geq 12$ termasuk dalam kategori tinggi.

\section{Penutup}

\section{Kesimpulan}

a. Efektivitas implementasi sistem modul belajar Akuntansi pada kelas XI Kompetensi keahlian Akuntansi SMK Negeri 1 Yogyakarta tahun ajaran 2012/2013 ditinjau dari perspektif guru 
secara keseluruhan termasuk dalam kategori tinggi (efektivitas tinggi). Pencapaian untuk masing-masing indikator adalah sebagai berikut:

1) Indikator pertama yaitu kemudahan dalam penyampaian materi ditinjau dari perspektif guru termasuk dalam kategori efektivitas tinggi. Hal ini berarti implementasi sistem modul belajar Akuntansi ditinjau dari perspektif guru telah dapat mempermudah dalam penyampaian materi pelajaran.

2) Indikator kedua yaitu terdapat solusi atas keterbatasanketerbatasan dalam pembelajaran ditinjau dari perspektif guru termasuk dalam kategori efektivitas tinggi. Hal ini berarti implementasi sistem modul belajar Akuntansi ditinjau dari perspektif guru telah memberikan solusi atas keterbatasanketerbatasan yang terdapat dalam proses pelajaran.

3) Indikator ketiga yaitu variasi dalam proses pembelajaran ditinjau dari perspektif guru termasuk dalam kategori efektivitas tinggi. Hal ini berarti implementasi sistem modul belajar Akuntansi ditinjau dari perspektif guru telah dapat menciptakan variasi dalam pelaksanaan proses pembelajaran.

4) Indikator keempat yaitu adanya penilaian diri (self assessment) ditinjau dari perspektif guru termasuk dalam kategori efektivitas tinggi. Hal ini berarti implementasi sistem modul belajar Akuntansi ditinjau dari perspektif guru telah dapat membantu siswa untuk melakukan penilaian diri (self assessment).

5) Indikator kelima yaitu pembelajaran tuntas (mastery learning)ditinjau dari perspektif guru termasuk dalam kategori efektivitas tinggi. Hal ini berarti implementasi sistem modul belajar Akuntansi ditinjau dari perspektif guru telah dapat membantu siswa untuk mempelajari materi hingga tuntas.

b. Efektivitas implementasi sistem modul belajar Akuntansi pada kelas XI Kompetensi keahlian Akuntansi SMK Negeri 1 Yogyakarta tahun ajaran 2012/2013 ditinjau dari perspektif siswa secara keseluruhan termasuk dalam kategori tinggi (efektivitas tinggi). Hal ini dapat dilihat rerata hitungnya yaitu sebesar 116,63. Rerata hitung tersebut kemudian dibandingkan dengan skor dalam kriteria kategori yaitu sebesar 105 dimana untuk skor $\geq 105$ termasuk dalam kategori tinggi. Pencapaian untuk masing-masing indiator adalah sebagai berikut:

1) Indikator pertama yaitu kemudahan dalam penyampaian materi ditinjau dari perspektif siswa termasuk dalam kategori efektivitas tinggi. Hal ini berarti implementasi sistem modul belajar Akuntansi ditinjau dari perspektif siswa telah dapat mempermudah siswa dalam mempelajari materi yang disampaikan oleh guru.

2) Indikator kedua yaitu terdapat solusi atas keterbatasanketerbatasan dalam pembelajaran ditinjau dari perspektif 
siswa termasuk dalam kategori efektivitas tinggi. Hal ini berarti implementasi sistem modul belajar Akuntansi ditinjau dari perspektif siswa telah membantu siswa untuk mengatasi keterbatasan-keterbatasan yang terdapat dalam proses pelajaran.

3) Indikator ketiga yaitu variasi dalam proses pembelajaran ditinjau dari perspektif siswatermasuk dalam kategori efektivitas tinggi. Hal ini berarti implementasi sistem modul belajar Akuntansi ditinjau dari perspektif siswa telah dapat menciptakan variasi dalam pelaksanaan proses pembelajaran.

4) Indikator keempat yaitu adanya penilaian diri (self assessment) ditinjau dari perspektif siswatermasuk dalam kategori efektivitas tinggi. Hal ini berarti implementasi sistem modul belajar Akuntansi ditinjau dari perspektif siswa telah dapat membantu siswa untuk melakukan penilaian diri (self assessment).

5) Indikator kelima yaitu pembelajaran tuntas (mastery learning)ditinjau dari perspektif siswa termasuk dalam kategori efektivitas tinggi. Hal ini berarti implementasi sistem modul belajar Akuntansi ditinjau dari perspektif siswa telah dapat membantu siswa untuk mempelajari materi hingga tuntas.

\section{Saran}

a. Guru diharapkan agar tetap mempertahankan implementasi sistem modul belajar Akuntansi dalam proses pembelajaran Akuntansi dengan pengimplementasian yang sesuai dengan tujuan awal penyusunan modul agar implementasi sistem modul belajar Akuntansi dapat memberikan banyak manfaat dan keuntungan bagi guru maupun siswa.

b. Guru diharapkan untuk meningkatkan cara mengajarnya di kelas khususnya pada saat penyampaian materi pada siswa serta meningkatkan interaksi dengan siswa pada saat proses pembelajaran dengan modul Akuntansi agar tujuan pembelajaran dapat dicapai secara maksimal. Selain itu, guru juga diharapkan untuk menciptakan variasi dalam proses pembelajaran dengan menciptakan metode pembelajaran yang lebih bervariatif.

c. Pada saat implementasi sistem modul belajar Akuntansi Guru diharapkan untuk mendorong siswa agar meningkatkan frekuensi membaca dan belajarnya agar kecepatan belajar yang dimiliki siswa dapat meningkat. Selain itu, siswa juga diharapkan untuk meningkatkan kemandirian belajarnya pada saat implementasi sistem modul belajar dan mengurangi ketergantungannya pada guru. 


\section{E. DAFTAR PUSTAKA}

Akhmad Sudrajat. (2008). Sumber Belajar untuk Mengefektifkan Pembelajaran Siswa. (http://akhmadsudrajat.wordpress.com, diakses 1 Oktober 2012).

Al-bantany.(2009). Kumpulan Teori Efektivitas. (http://al-bantany112.blogspot.com, diakses 22 Oktober 2012).

Ali Mudlofir. (2011). Aplikasi Pengembangan Kurikulum Tingkat Satuan Pendidikan dan Bahan Ajar. Jakarta: Rajawal Press.

BSNP.(2006). Panduan Penyusunan Kurikulum Tingkat Satuan Pendidikan Jenjang Sekolah Dasar dan Menengah. Jakarta: BSNP

Chatarina Yudawati Setyaningsih. (2010). "Efektivitas Penggunaan Modul Akuntansi Siswa Kelas XI Jurusan IPS SMA Negeri 1 Sayegan Tahun Ajaran 2009/2010".Skripsi. Yogyakarta: FE UNY.

Depdiknas.(2002). Teknik Belajar dengan Modul. Jakarta: Dikmenjur. . (2008). Teknik Penyusunan Modul. Jakarta: Dikmenjur. . (2005). Undang-Undang Republik Indonesia Nomor 14 Tahun 2005 Tentang Sistem Pendidikan Nasional. Jakarta: Depdiknas.

Direktorat Tenaga Kependidikan Direktorat Jendral Peningkatan Mutu Pendidik dan Tenaga Kependidikan Departemen Pendidikan Nasional.(2008). Pedoman Penulisan Modul. Jakarta: Depdiknas.

Enco Mulyasa. (2006). Kurikulum yang Disempurnakan. Bandung: PT. Rosdakarya.

(2009). Menjadi Guru Profesional Menciptakan Pembelajaran Kreatif, dan Menyenangkan.Bandung: PT Remaja Rosdakarya.

Martinis Yamin.(2007). Kiat Membelajarkan Siswa. Jakarta: Gaung Persada Press

Nana Syaodih.(2009). Landasan Psikologi Proses Pendidikan. Bandung: PT Remaja Rosdakarya

Nurul Zuriah. (2007). Metodologi Penelitian Sosial dan Pendidikan. Jakarta: Bumi Aksara

Oemar Hamalik. (2009). Dasar-dasar Pengembangan Kurikulum. Bandung: PT Remaja Rosdakarya . (2010). Perencanaan Pengajaran Berdasarkan Pendekatan Sistem. Jakarta: Bumi Aksara . (2011). Kurikulum dan Pembelajaran. Jakarta: Bumi Aksara

Reni Suryandari. (2010). "Efektivitas Implementasi Modul belajar Akuntansi pada kelas X Program Keahlian Akuntansi SMK N 1 Wonosari tahun ajaran 2009/2010”.Skripsi. Yogyakarta: FE UNY.

Rizal Septa Dwi Raharjo. (2009). "Efektivitas Penggunaan Modul Terhadap Hasil Belajar Siswa Kelas X pada Mata diklat Ekonomi di SMA N 1 Karangan Trenggalek Tahun pelajaran 2008/2009”. Skripsi. Yogyakarta: FE UNY. 
Jurnal Pendidikan Akuntansi Indonesia, Vol. XI, No. 1, Tahun 2013 Ninda Okta Winggani\&Sukanti

Halaman $50-66$

S. Nasution. (2011). Berbagai Pendekatan dalam Proses Belajar dan Mengajar. Jakarta: Bumi Aksara.

Saiffudin Azwar. (2004). Metode Penelitian. Yogyakarta: Pustaka Pelajar (2011). Penyusunan Skala Psikologi. Yogyakarta: Pustaka Pelajar.

Sugihartono, dkk.(2007). Psikologi Pendidikan. Yogyakarta: UNY Press.

Sugiyono. (2007).Statistika untuk Penelitian.Bandung: CV Alfabeta. . (2010). Metode Penelitian Pendidikan. Bandung: CV Alfabeta.

Suharsimi Arikunto. (2009). Dasar-Dasar Evaluasi Pendidikan. Jakarta: Bumi Aksara.

Wina Sanjaya. (2011). Strategi Pembelajaran Berorientasi Standar Proses Pendidikan. Jakarta: Kencana Prenada Media. 